\title{
The effect of ruminal infusion of acetic, propionic and butyric acids on eating, rumination behaviour and feed utilization in sheep fed on urea- supplemented roughage
}

\author{
T. Fujihara', S. Maeda and M.N. Shem ${ }^{2}$ \\ Faculty of Life and Environmental Science, Shimane University \\ Matsue-shi, Shimane 690-8504, Japan
}

(Received 11 June 2001; revised version 26 November 2001; accepted 31 January 2002)

\begin{abstract}
Two experiments were conducted to investigate the effect of ruminal infusion of volatile fatty acids (VFAs) on eating and rumination behaviour and feed utilization in sheep fed on hay. The amounts infused were 300,300 and $150 \mathrm{kcal}$ per day per animal of acetic, propionic and butyric acids, respectively. Each acid solution was continuously infused into the rumen of sheep fed on timothy hay alone (Experiment I). In Experiment II, sheep fed on roughage with varied crude protein (CP) levels $(6.0,7.3,9.1$ and $15.5 \%$ DM). Four sheep, two in each, were used in repeated crossover designed experiments. Daily eating time was lengthened by infusion of acetic and propionic acids as compared to control. There was no change in eating time after infusion of butyric acid (Experiment I). Daily eating time increased after propionic acid infusion and change in CP contents of the basal diet compared to control sheep. There was no change in eating time after infusion of acetic acid (Experiment II). Rumination appearance tended to shorten after infusion of acetic and propionic acids as comparcd to that of control. Butyric acid infusion gave opposite (Experiment l). Rumination appearance was Jong with an increase in dietary $\mathrm{CP}$, but was not changed by ruminal infusion of volatile fatty acids (Experiment II). Daily rumination time tended to be long after infusion of butyric acid and short after in lusion of acetic acid, and did not change after infusion of propionic acid (Experiment I). Cyclic rate tended to lengthen after infusion of acetic acid as compared to that of control, but there was no change after infusion of propionic and butyric acids (Experiment I). Cyclic rate was shortened after infusion
\end{abstract}

1 Corresponding author

2 Present address: Department of Animal Science and Production, Sokoine University of Agriculture, P.O. Box 3004, Chuo Kikuu, Morogoro, Tanzania 
of acetic acid regardless of the CP content in the diet compared to that of control. Ruminal infusion of propionic acid had no clear effect on cyclic rate in sheep fed on diets with varied CP contents (Experiment 11). Rumination appearance was fairly changed with varying levels dietary CP content regardless ruminal VFAs infusion. It was therefore, concluded that ruminal infusion of VFAs had little effect on eating and rumination behaviour and feed utilization. It was further concluded that chemical stimulus rather than physical stimuli, such as the increment of ruminal nitrogen could influence the chemoreceptor on the rumen wall.

KEY WAORD: eating behaviour, rumen, rumination, VFAs infusion, sheep, fecd utilization

\section{INTRODUCTION}

Rumination behaviour contributes to the increase in utilization of roughage feeds through particle size reduction, which facilitates their degradation in the rumen. Particle size reduction through re-mastication of the feed improves rumen microbial and fermentation activities (Welch and Smith, 1969). Rumination behaviour is closely related to the amount of feed ingested (Gordon, 1965; Fujihara et al., 1990b) and is influenced by changes in physical properties and/or chemical composition of feed ingested (Gordon, 1958; Fujihara, 1980; Fujihara and Nakao, 1990a; Mawuenyegah et al., 1997). Rumination is initiated by the presence of ruminal ingesta by chemical and/or physical stimuli to receptors in the rumen wall (Fujihara et al., 1989). However, the exact mechanism involved is not clearly known (Fujihara and Nakao, 1990b).

Rumination index (time spent ruminating per $100 \mathrm{~g}$ DM intake), which also defines rumination efficiency, is highly influenced by the chemical and physical quality of the feed (Dryden et al., 1995). The products of rumen fermentation (VFAs) and the extent of ruminal fermentation are closely related to rumination behaviour. Infusion of acetic acid into the rumen alone has no significant effect on rumination behaviour in sheep fed on low quality hay. The type and form of forage eaten and significantly the amount of crude protein fed seem to also play a great role (Fujihara et al., 2002b). Increasing protein (Fujihara and Nakao, 1984) and energy supply (Weston, 1996; Mawuenyegah et al., 1997) to the rumen helps in maintenance of optimal rumen condition from microbial growth and fibre digestion resulting in higher voluntary intake.

The objectives of this study were to investigate the effect of infusing VFAs alone on the eating, rumination behaviour and feed utilization on sheep fed on hay diets (Experiment I). The effect of ruminal infusion of acetic and propionic acids with varied $\mathrm{CP}$ levels in the form of urea on eating, rumination behaviour and feed utilization in sheep fed on grass hay diets was also investigated (Experiment II). Fujihara et al. (1990a) have briefly described part of this work. 


\section{MATERIAL AND METHODS}

\section{Treatment and design}

Experiment I. Two Japanese Corriedale wethers were fed on a basal diet of timothy hay (CP: $9.1 \sim 10.0 \%$ ) with or without ruminal infusion of acetic, propionic and butyric acids in a repeated measurement cross over expcriment (Table 1). Each period lasted for 12 days ( 7 for preliminary and 5 for sampling). Infusion of acetic and propionic acids were done using the same procedures as described by Fujihara et al. (2002a). Butyric acid was infused at the rate $12 \mathrm{mmol} / \mathrm{h}$ during $24 \mathrm{~h}$, which was estimated to be able to supply $150 \mathrm{kcal}$ per day per head.

Experiment II. Two crossbred female lambs were fed on three basal diets of hay with or without ruminal infusion of acetic and propionic acids in a repcated measurement crossover experiment also in three periods of similar duration as in experiment one. The three basal hays used were timothy hays $(6.6 \%$ or Italian ryegrass hay, $7.3 \%$ of CP per DM); timothy hay $(9.1 \%$ of CP per DM); timothy hay supplemented with urea $(15.5 \% \mathrm{CP}$ per DM). The same technique of ruminal infusion of VFA acids used in experiment one was also applied.

TABLE 1

Experimental design

\begin{tabular}{|c|c|c|c|c|c|c|}
\hline \multicolumn{7}{|l|}{ Experiment I } \\
\hline & \multicolumn{2}{|c|}{ Period I } & \multicolumn{2}{|c|}{ Period II } & \multicolumn{2}{|c|}{ Period III } \\
\hline Basal diet (hay) & \multicolumn{2}{|c|}{ Timothy (B) } & \multicolumn{2}{|c|}{ Timothy (B) } & \multicolumn{2}{|c|}{ Timothy (C) } \\
\hline Acid infused & \multicolumn{2}{|c|}{ acetic acid } & \multicolumn{2}{|c|}{ propionic acid } & \multicolumn{2}{|c|}{ butyric acid } \\
\hline Treatment & control & infusion & control & infusion & control & infusion \\
\hline \multicolumn{7}{|c|}{ Allocation of animals } \\
\hline $1^{\text {st }}$ term $^{*}$ & A & $\mathrm{B}$ & A & $\mathrm{B}$ & A & B \\
\hline $2^{\text {nd }}$ term & $\mathrm{B}$ & A & B & A & B & A \\
\hline
\end{tabular}

Experiment II

\begin{tabular}{|c|c|c|c|c|c|c|}
\hline \multirow{4}{*}{$\begin{array}{l}\text { Basal diet } \\
\text { CP of basal diet }(\%) \\
\text { Treatment }\end{array}$} & \multicolumn{2}{|c|}{ Period I } & \multicolumn{2}{|c|}{ Period II } & \multicolumn{2}{|c|}{ Period III } \\
\hline & \multicolumn{2}{|c|}{ Timothy (A)' } & \multicolumn{2}{|c|}{ Timothy (B) } & \multicolumn{2}{|c|}{ Timothy (B)+Urea } \\
\hline & \multicolumn{2}{|c|}{$6.6(7.3)^{1}$} & \multicolumn{2}{|c|}{9.1} & \multicolumn{2}{|c|}{15.5} \\
\hline & control & infusion ${ }^{2}$ & control & infusion & control & infusion \\
\hline \multicolumn{7}{|l|}{ Allocation of animals } \\
\hline $1^{\mathrm{sl}} \mathrm{term}^{4}$ & C & $\mathrm{D}$ & $\mathrm{C}$ & $\mathrm{D}$ & $\mathrm{C}$ & D \\
\hline $2^{\text {nd }}$ term & $\mathrm{D}$ & $\mathrm{C}$ & $\mathrm{D}$ & $\mathrm{C}$ & D & $\mathrm{C}$ \\
\hline
\end{tabular}

" consecutive 12 days for each treatment (7-day: preliminary, 5-day: sampling)

1 in propionic acid infusion, Italian ryegrass hay was used in period 1

2 ruminal infusion of acetic acid and propionic acid 
Animals, diets and management

The four sheep (two Japanese Corriedale wethers for Experiment I and II crossbred Suffolk x Japanese Corriedale female lambs for Experiment II), weighing 38$45 \mathrm{~kg}$ and fitted with ruminal cannulae were used. The sheep were kept in metabolism cages throughout the experimental period. They were fed on $2.0 \sim 2.2 \%$ dry matter (DM) of each hay per kg body weight per day. Three types of timothy and one type of Italian ryegrass hays were used. Their chemical composition is as shown in Table 2. Before feeding, hay was chopped to about $4 \mathrm{~cm}$ long. One-half of the daily rations were given at 09.00 and the other half at 17.00 .

Fresh water and salt licks containing trace elements were made available at all times throughout the trial. Refusals were weighed, sampled everyday, bulked and sub-sampled every week for their chemical analysis.

TABLE 2

Chemical composition of hay diet, \% of DM

\begin{tabular}{lrrrr}
\hline \multirow{2}{*}{ Diet } & \multicolumn{3}{c}{ Timothy } & Italian ryegrass \\
\cline { 2 - 4 } & \multicolumn{1}{c}{ (A) } & $(\mathrm{B})$ & \multicolumn{1}{c}{ (C) } & \\
\hline Organic matter & $93.7^{1}$ & 93.5 & 94.6 & 87.1 \\
Crude protein & 6.6 & 9.1 & 10.0 & 7.3 \\
Crude fat & 2.3 & 2.5 & 3.3 & 2.8 \\
Crude fibre & 34.9 & 32.8 & 34.7 & 37.8 \\
NFE' & 49.9 & 49.1 & 46.6 & 39.3 \\
\hline
\end{tabular}

1 nitrogen free extractives

Sample collection and analytical methods

In each experimental period, sampling was done for five days following a seven-day preliminary period. Faeces and urine samples were collected daily from the experimental animals before feeding each morning. The samples for ruminal contents and jugular blood were collected on the final day of the experiment in each period as the same manner in the previous report of Fujihara et al. (2002a). Analytical techniques for chemical analysis of feed, excreta, ruminal contents and blood plasma, and the method for measuring eating and rumination behaviour were similar to those used by Fujihara et al. (2002a).

Test for significance of difference between the treatment means for repeated measurement were compared using $t$-test (Stats View, 1999; SAS Institute Inc., SAS Campus Drive, Cary, NC 27513).

The nitrogen $(\mathrm{N})$ balance was indicated as $\mathrm{g}$ per $\mathrm{kg}$ of metabolic body size to correct a variance metabolism according with different body weight of animals. 


\section{RESULTS}

\section{Eating behaviour}

In Experiment I, time spent eating per day was increased in sheep infused with acetic and propionic acids. There were fewer decreases with butyric acid infusion (Table 3 ). Infusions had no significant effect $(\mathrm{P}<0.05)$ on eating time and rate of eating. Infusions with acetic and propionic acids led to decreased rumination appearance (lag time after eating) in sheep while it was increased by butyric acid.

In Experiment II however, time spent eating per day did not change with acetic acid infusion and eating time took longer time in sheep fed on low-CP hay (Table 3). Rumination appearance took longer in sheep fed on hay with increasing $\mathrm{CP}$ content and was not changed by infusion of VFAs. Daily eating time was prolonged $(\mathrm{P}>0.05)$ by infusion with propionic acid regardless the CP content and type of hay eaten. Consequently, eating rate was slightly decreased in sheep fed hay containing variable $\mathrm{CP}$ contents.

\section{Rumination behaviour}

In Experiment I, daily ruminating time decreased in sheep infused with acetic acid as compared with those on control, but was almost same in those infused with propionic acid and compared to control. Similar results were obtained for butyric acid infused sheep, which also showed no change in daily ruminating time (Table 4). The number of boli regurgitated daily tended to increase $(\mathrm{P}>0.05)$ in acetic and butyric acids infused sheep. Similarly, infusion with propionic acid, $\operatorname{did} \operatorname{not}(\mathrm{P}>0.05)$ change the daily number of boli regurgitated by sheep so did rumination period in the whole experiment. The rumination index (time spent ruminating/100 g DM eaten) decreased only after ruminal infusion of acetic acid but not change after infusion with propionic or butyric acid.

In Experiment II, infusion with acetic acid significantly $(P<0.05)$ decreased daily time spent ruminating by sheep on low CP $(6.6 \%)$ hay than those on control. Time spent ruminating by sheep on high $\mathrm{CP}(15.5 \%)$ hay tended to be longer with infusion but not significantly $(\mathrm{P}>0.05)$. The number of boli regurgitated daily by sheep on low CP (6.65) hay tended to decrease after infusion with acetic acid, but was slightly increased $(\mathrm{P}>0.05)$ in sheep fed high $\mathrm{CP}(9.9 \sim 15.5 \%)$ hay after infusion with acetic acid. The number of daily rumination periods tended to increase with an increase in dietary $\mathrm{CP}$ both in the acid infused and control groups. Cyclic rate (total rumination time (s)/number of boli regurgitated) tended to be shorter after infusion with acetic acid regardless of dietary $\mathrm{CP}$ level, and the difference in values with or without infusion of acetic acid was significantly $(\mathrm{P}<0.05)$ in sheep 
ที丶்

$+1+1+1+1$

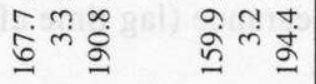

$\overrightarrow{+} \overrightarrow{0} \ddot{n}$

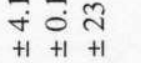

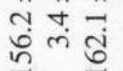

तुํำ

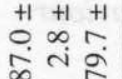

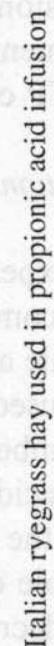

ํํ유

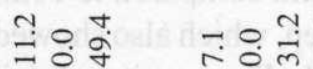

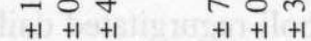

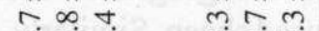

ปั่

का.

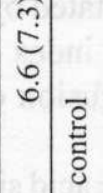

$\begin{array}{lll}+1 & +1 & +1 \\ \infty & 0 & 0\end{array}$

穸

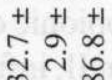

을 2

. 클

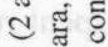

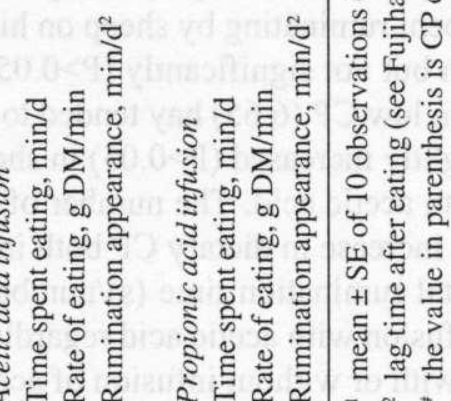




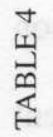

ह

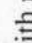

త

วิ

ธี

¿

$\frac{0}{4}$

$\cong$

흥

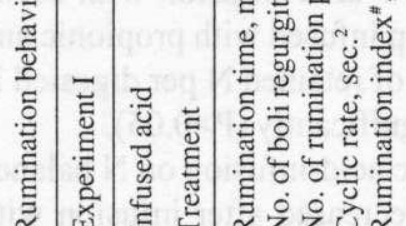

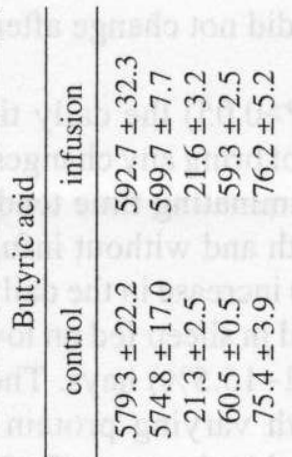

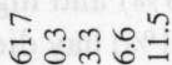

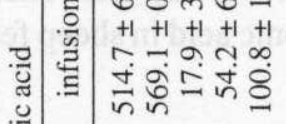

흥

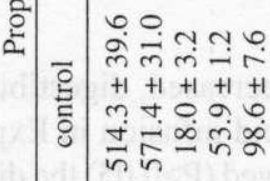

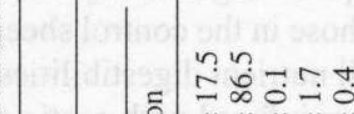

$+1+1+1+1+1$

तु

믈

ปั

กิํํำ

$+1+1+1+1$

$\infty$ m mo

ฝิ

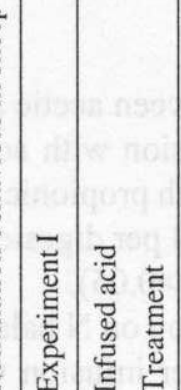

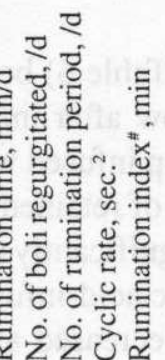

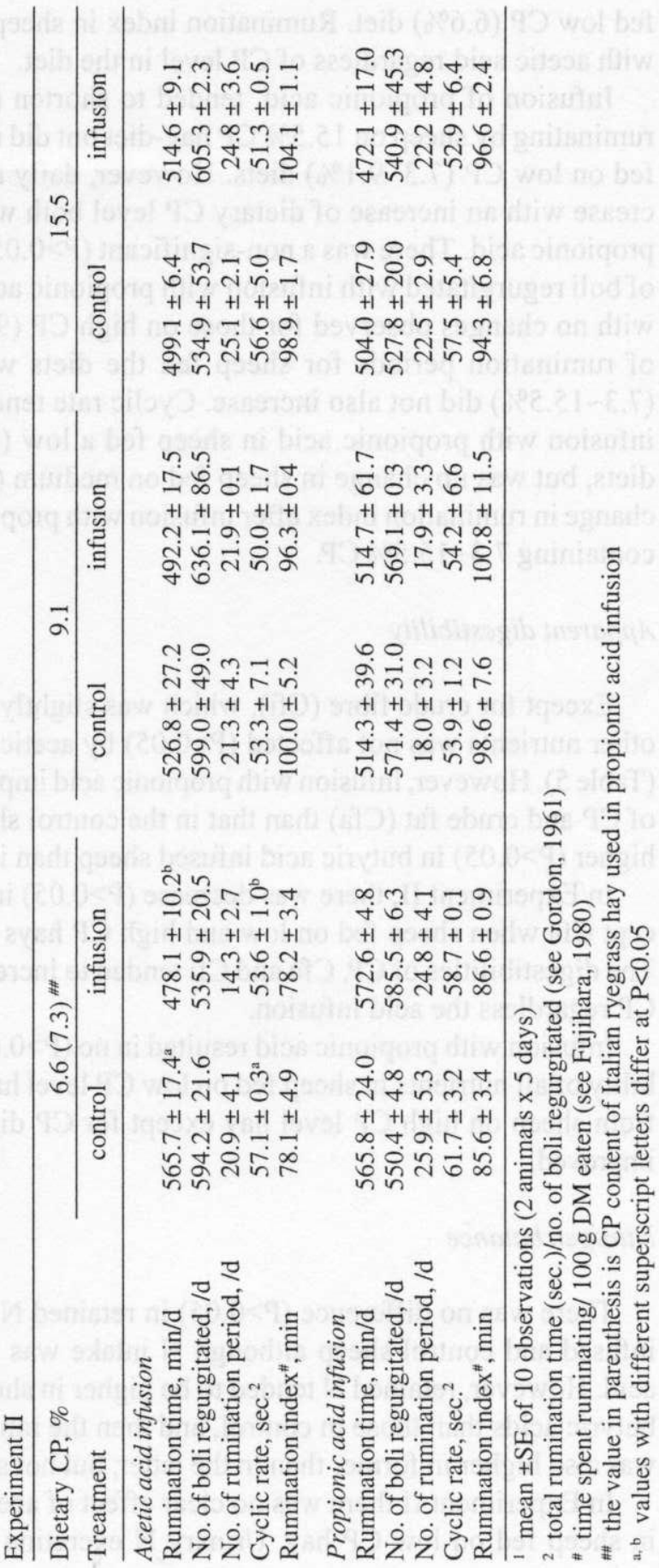


fed low CP $(6.6 \%)$ diet. Rumination index in sheep did not change after infusion with acetic acid regardless of $\mathrm{CP}$ level in the diet.

Infusion of propionic acid, tended to shorten $(\mathrm{P}>0.05)$ the daily time spent ruminating by sheep on $15.5 \% \mathrm{CP}$ hay-diet but did not bring any changes in sheep fed on low CP $(7.3 \sim 9.1 \%)$ diets. However, daily ruminating time tended to decrease with an increase of dietary $\mathrm{CP}$ level both with and without infusion with propionic acid. There was a non-significant $(P>0.05)$ increase in the daily number of boli regurgitated with infusion with propionic acid in sheep fed on low $\mathrm{CP}$ diet with no changes observed for those on high $\mathrm{CP}(9.1 \sim 15.5 \%)$ hays. The number of rumination periods for sheep fed the diets with varying protein contents (7.3 15.5\%) did not also increase. Cyclic rate tended to decrease $(\mathrm{P}>0.05)$ after infusion with propionic acid in sheep fed a low (7.3\%) and high (15.5\%) haydiets, but was no change in sheep fed on medium (9.1\%) hay diet. There was no change in rumination index after infusion with propionic acid in sheep fed hay diet containing $7.3 \sim 15.5 \% \mathrm{CP}$.

\section{Apparent digestibility}

Except for crude fibre (Cfi), which was slightly decreased, digestibility of the other nutrients was not affected $(\mathrm{P}>0.05)$ by acetic acid infusion in Experiment I (Table 5). However, infusion with propionic acid improved $(P>0.05)$ the digestibility of $\mathrm{CP}$ and crude fat ( $\mathrm{Cfa}$ ) than that in the control sheep. $\mathrm{CP}$ digestibility was also higher $(\mathrm{P}>0.05)$ in butyric acid infused sheep than in those in the control sheep.

In Experiment II, there was decrease $(\mathrm{P}>0.05)$ in all nutrient digestibilities except $\mathrm{Cfa}$ when sheep fed on low and high CP hays were infused with acetic acid. The digestibilities of $\mathrm{CP}, \mathrm{Cfa}$ and $\mathrm{Cfi}$ tended to increase with an increase of dietary $\mathrm{CP}$ regardless the acid infusion.

Infusion with propionic acid resulted in no $(\mathrm{P}>0.05)$ change in apparent digestibility of all nutrients in sheep fed on low $\mathrm{CP}$ level hay. Same results were obtained from sheep on high $\mathrm{CP}$ level hay except for $\mathrm{CP}$ digestibility, which was slightly improved.

\section{Nitrogen balance}

There was no difference $(P>0.05)$ in retained $N$ (Table 6$)$ between acetic acid infused and control sheep although $\mathrm{N}$ intake was low after infusion with acetic acid. However, retained $N$ tended to be higher in sheep infused with propionic and butyric acids than those in control, and then the ratio of retained $\mathrm{N}$ per digested $\mathrm{N}$ was also higher in former than in the latter, but not significantly $(P>0.05)$.

In Experiment II there was no clear effect of acetic acid-infusion on $\mathrm{N}$ balance in sheep fed on low $\mathrm{CP}$ hay. Urinary $\mathrm{N}$ excretion decreased after infusion with 
告

出

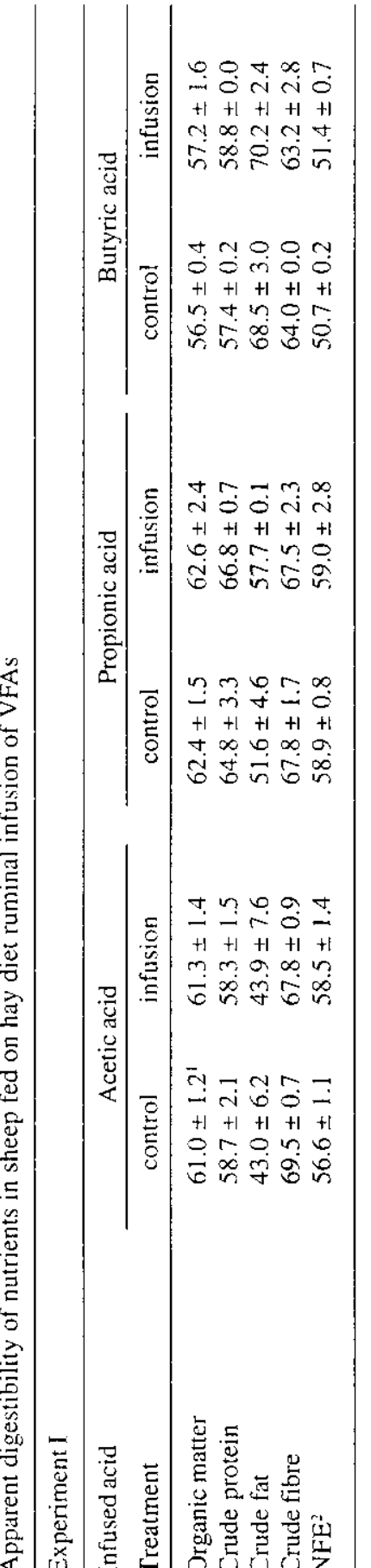

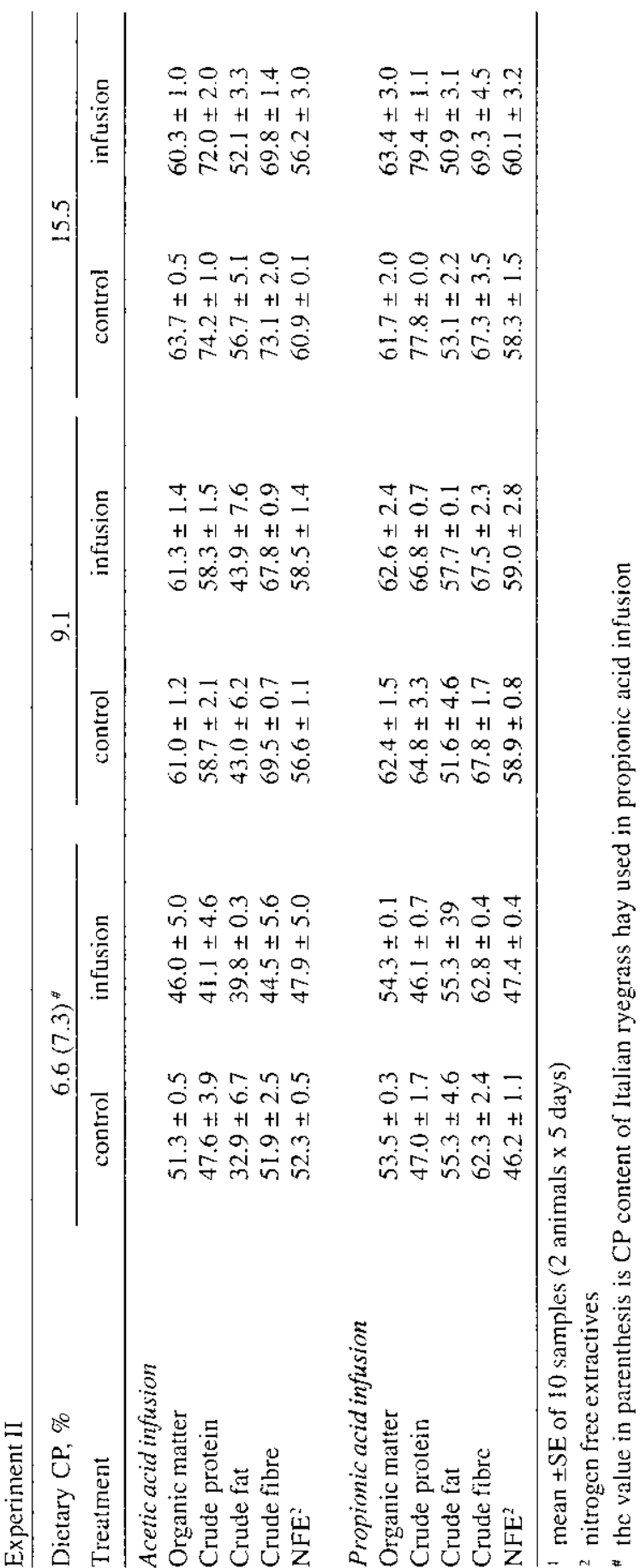




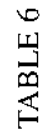
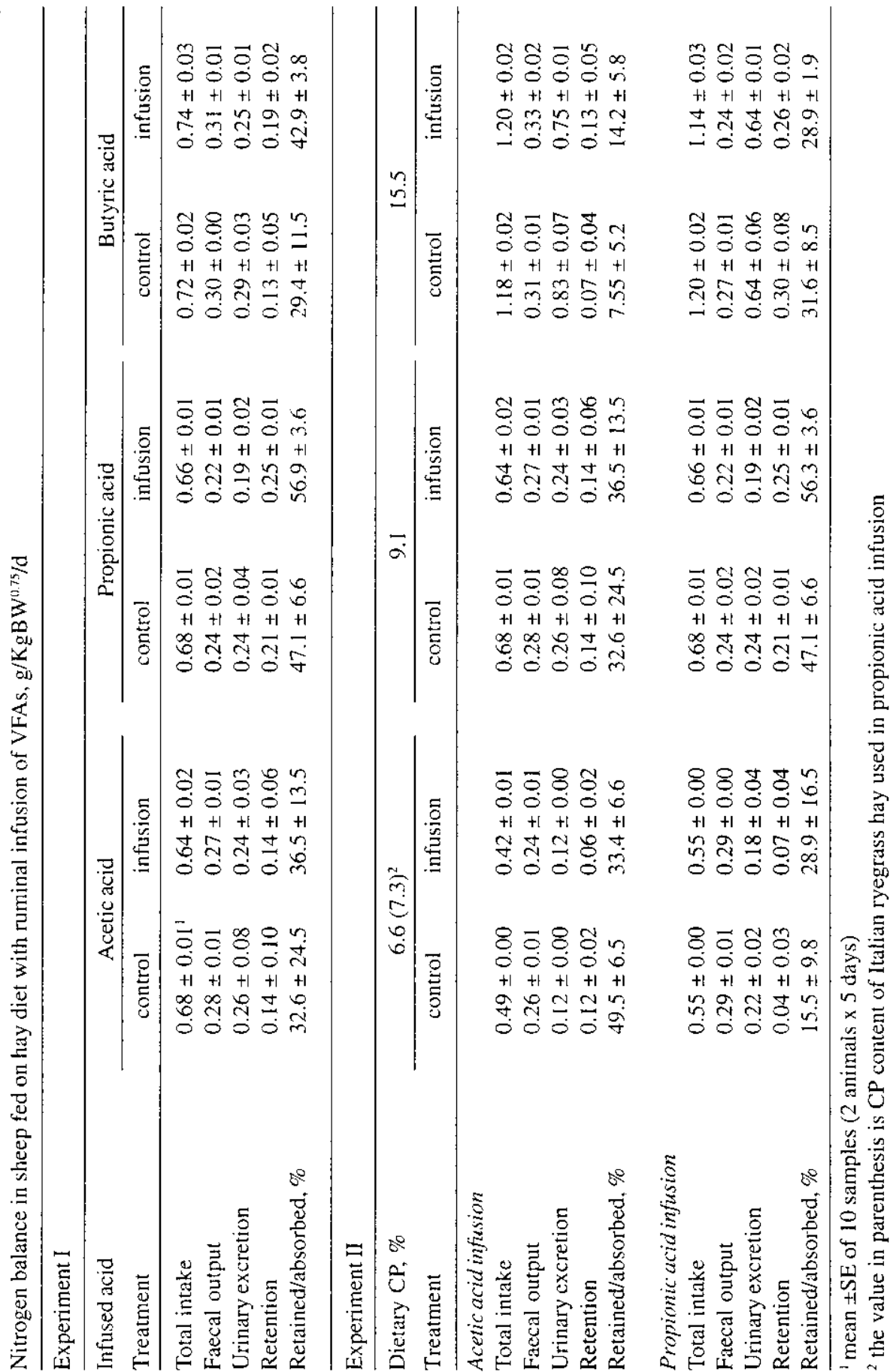
acetic acid and the ratio of retained $\mathrm{N}$ per digested $\mathrm{N}$ also increased in sheep on high $\mathrm{CP}$ hays. Infusion with propionic acid of sheep fed on low CP diet resulted in reduced urinary $\mathrm{N}$ excretion and consequently in higher retained $\mathrm{N}$ compared to the control sheep. There was no difference $(\mathrm{P}>0.05)$ in $\mathrm{N}$ balance between sheep fed high $C P$ diet in with and without propionic acid infused sheep. Generally retained $\mathrm{N}$ increased with an increase in dietary $\mathrm{CP}$ level regardless the acid infusions.

\section{The changes in parameters of ruminal fermentation}

In Experiment I, rumen $\mathrm{pH}$ was lower and VFAs higher in sheep infused with acetic acid than in control (Table 7). Rumen ammonia levels were however, decreased with acetic acid infusion. Propionic acid infusion however, did not effect $(\mathrm{P}>0.05)$ on ruminal $\mathrm{pH}$ although VFAs concentrations were increased. Rumen ammonia decreased after infusion with propionic acid as compared with control. There was no $(\mathrm{P}>0.05)$ change in $\mathrm{pH}$ value, VFAs and ammonia contents in rumen of sheep infused with butyric acid.

Infusion of acetic and propionic acids had no ( $\mathrm{P}>0.05)$ effect rumen $\mathrm{pH}$ in sheep fed on hay diet containing 6.6 15.5\% CP. The concentration of VFAs in the rumen liquor increased after ruminal infusion of acetic acid in sheep fed hay containing $6.6 \sim 15.5 \% \mathrm{CP}$ but were low in sheep fed low CP $(7.3 \%)$ diet after infusion with propionic acid. Rumen ammonia decreased $(\mathrm{P}<0.05)$ with infusion of propionic acid in sheep fed high CP $(9.1 \sim 15.5 \%)$ diet compared to sheep fed low CP $(7.3 \%)$ diet.

The changes in concentrations of metabolites in the plasma

As shown in Table 8 in Experiment 1 the concentrations of urea and total protein in the plasma of sheep infused with acetic acid tended to be lower $(\mathrm{P}>0.05)$ as compared to that in control. There was also a little $(\mathrm{P}>0.05)$ change in plasma urea and total protein after infusion with propionic acid. Blood glucose did not increase after infusion with propionic acid as a glycogenic precursor. Plasma urea and total protein levels also were not affected $(\mathrm{P}>0.05)$ by infusion with butyric acids.

In Experiment II there was a little ( $P>0.05)$ difference in the concentration of plasma total protein after infusion with acetic acid of sheep fed hay containing $6.6 \sim 15.5 \% \mathrm{CP}$. The concentration of urea in blood plasma tended to decrease ( $P>0.05$ ) with infusion of acetic acid to sheep fed hay dicts containing 6.6 15.5\% CP. Similar results were obtained with propionic acid infusion, which on the other hand $(\mathrm{P}<0.05)$ increased blood glucose concentration in sheep fed low $\mathrm{CP}(7.3 \%)$ diet, which was lower in sheep fed high CP (15.5\%) diet. 
站

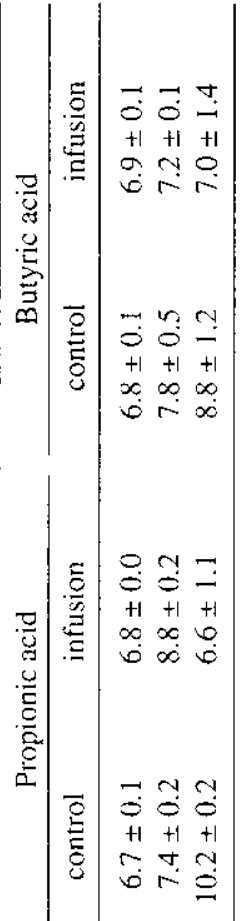

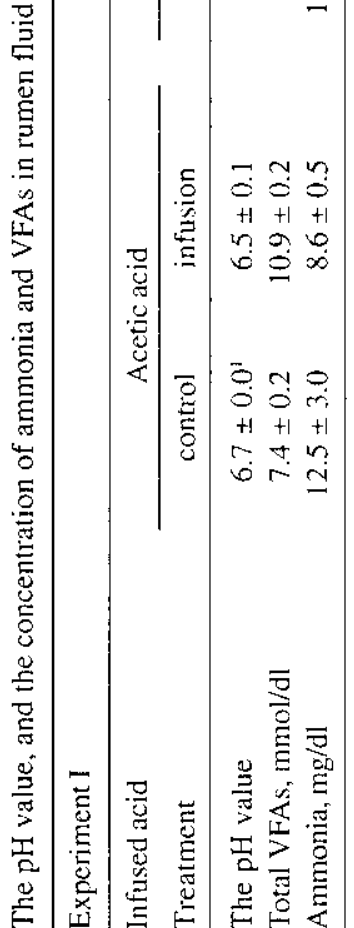

.

这

范

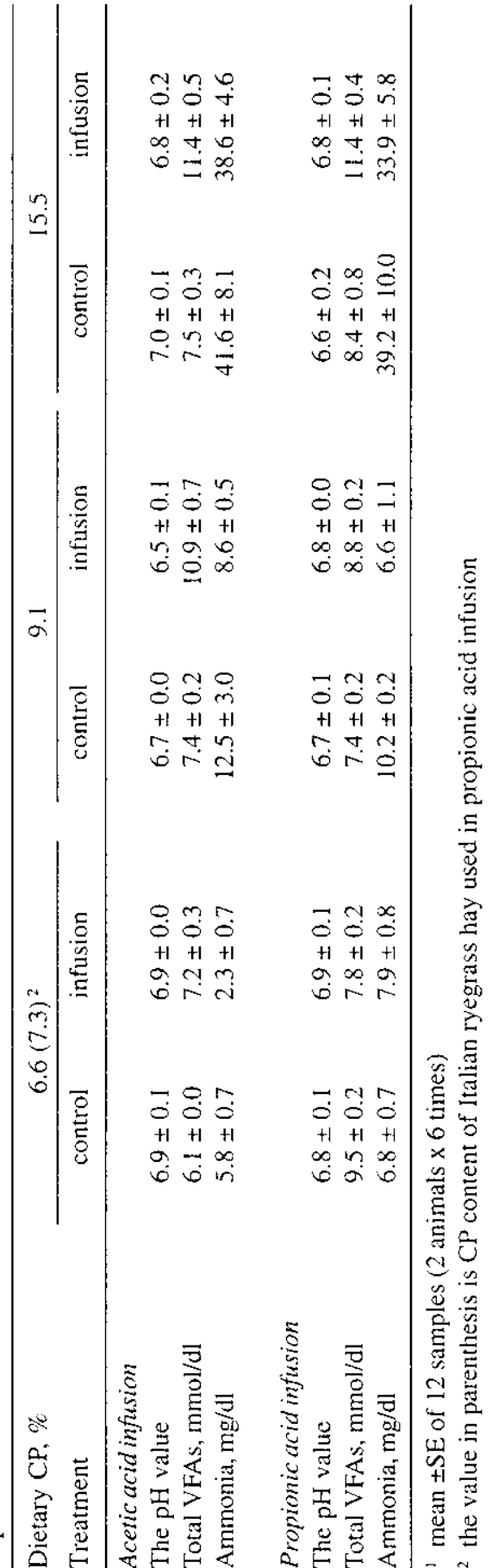




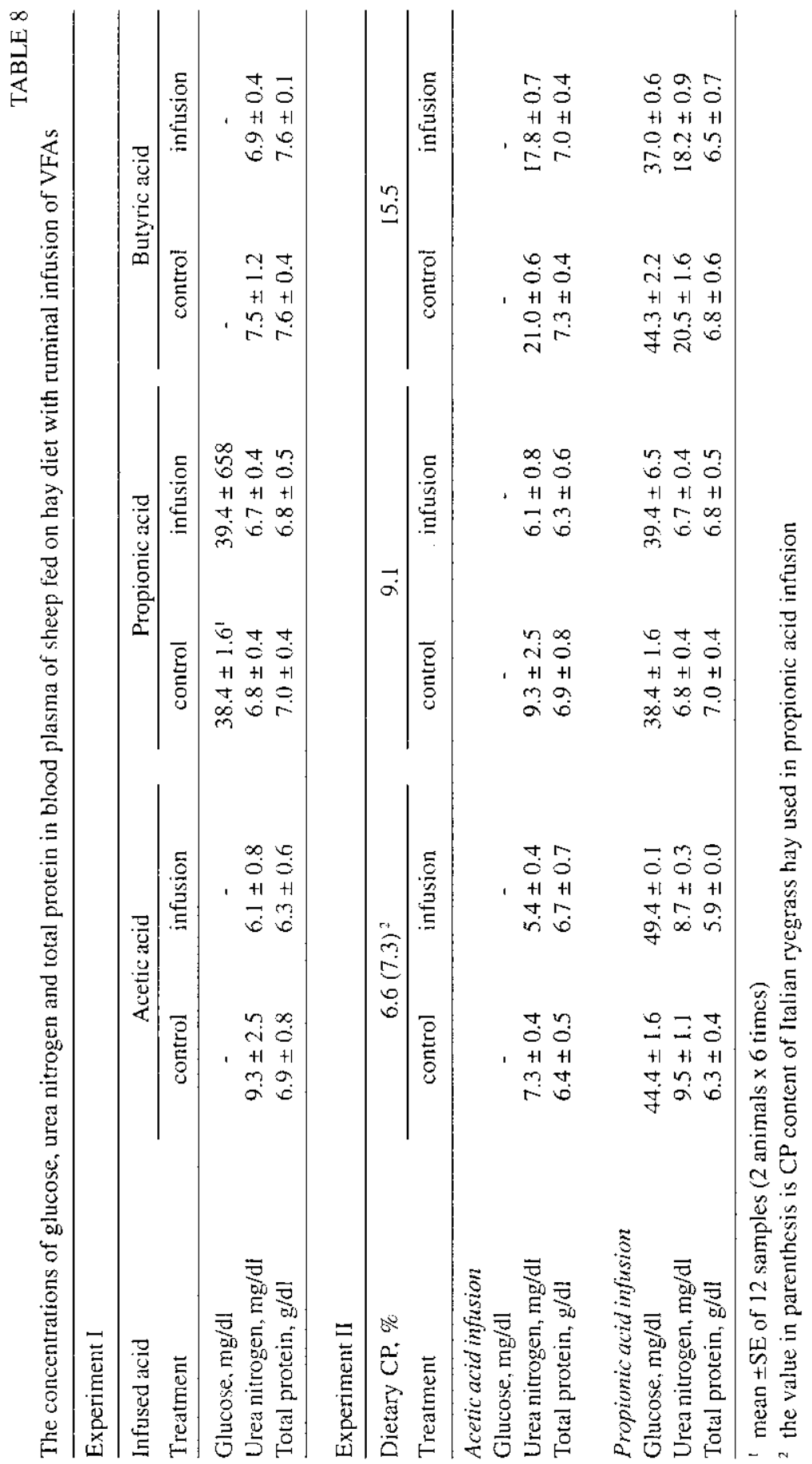




\section{The composition of VFAs in rumen contents}

In Experiment $I$, the level of acetic acid was increased $(P<0.05)$ with infusion of acetic acid, although the levels of propionic, butyric and $i s o$-valeric acids were lower than that in control (Table 9). The infusion of propionic acid had effect $(\mathrm{P}<0.05)$ on increased level of propionic acid in the rumen, but had no effect on levels of acetic and butyric acids. Infusion with butyric acid, resulted in a twofold increase in rumen butyric acid content compared to that in control. The levels of acetic and propionic acids in rumen however decreased $(\mathrm{P}<0.05)$ compared with that in control.

Results from Experiment II show that infusion with both acetic and propionic acids, increased the ratio of each acid in ruminal total VFAs to 2-3 times higher than that in control regardless the changes in level of dietary CP. However, the ratios of other acids with the exception of those infused were rather lower in infused sheep than in control.

\section{DISCUSSION}

Results from this study show that daily eating time and rate of eating were not significantly $(\mathrm{P}>0.05)$ changed by ruminal infusion of acetic and propionic acids, although there was no clear relationship between feed intake and ruminal VFAs infusion. According to Baile and Mayers (1969), infusion of VFAs into the rumen or the jugular vein reduced voluntary feed intake in goats. The authors attributed this to a receptor for acetic acid in the rumen wall. They also postulated that a similar receptor for propionic acid was located in the liver as well as in the rumen wall. Rumination appearance did not also change after ruminal infusion of VFAs. Similar results were reported by Fujihara et al. (2002a,b). With an increasing N intake, however, the lag time after eating tended to increase after infusions of acetic and propionic acids. From these results, it seems that a chemical stimuli caused by a change in dietary $\mathrm{CP}$ ingested is dominant factor controlling initiation of rumination. A conclusion was also reached by Fujihara et al. (2002b) in an experiment with sheep fed on high-CP hay.

According to Pearce (1965), there is a characteristic lag period after eating in sheep fed on hay with no clear change in this lag time when the rumen $\mathrm{pH}$ is 6.0 7.0. In the current study, rumen $\mathrm{pH}$ of $6.0 \sim 7.0$ after eating was ensured by VFAs infusion in the rumen with buffer solution to ensure rumination appearance. Increased salivation during eating is thought to delay initiation of rumination through salivary mucin, which coats the feed bolus before it enters the reticulo-rumen (Balch, 1958), creating a defensive wall between ingesta and receptors on the rumen wall. This is thought to prolong initiation of rumination during after eating. Increasing $\mathrm{N}$ intake and ruminal infusion of urea (NPN) in this experiment stimulated the coating 
닐

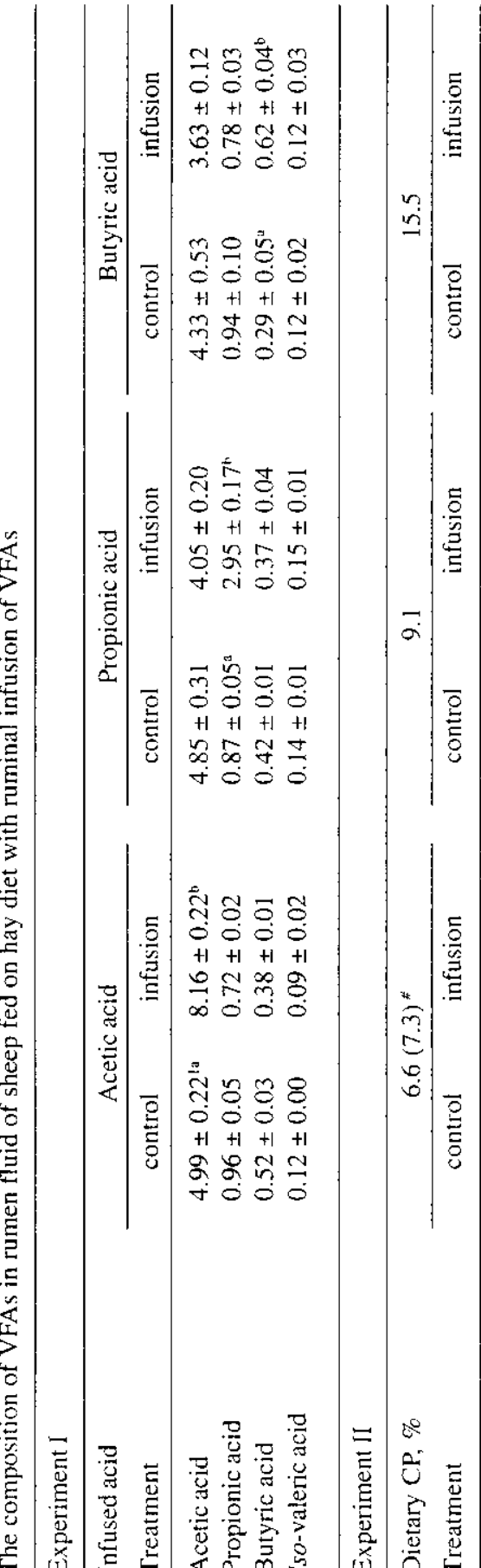

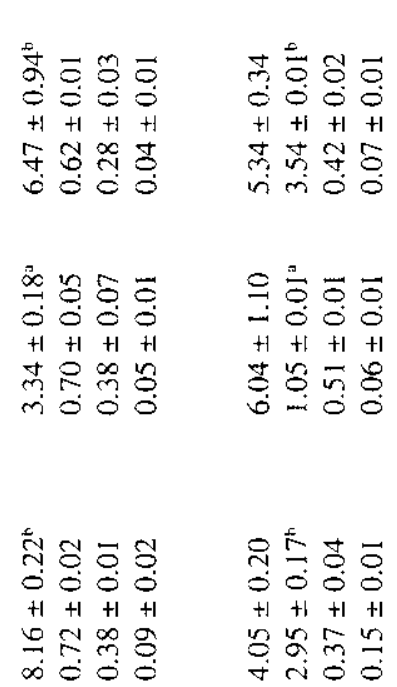

ปี่ லீ仓 $\begin{array}{llll}+1 & +1 & H\end{array}$ 용 $+1+1+1+1$

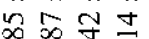
+ंல்

융응ํㅇㅇ 0000 H $+1+1+1$

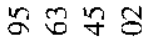
00000

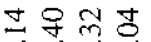
वंठठठ

तิ่ 0000 $+1+1+1+1$ ते 0ं $0 \dot{0} 0$ $\begin{array}{lll}+1 & +1 & +1 \\ 0 & 1 & 0\end{array}$ लठठठठ

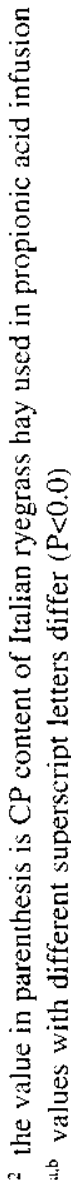


of ingesta with mucoprotein and subsequently decreasing physical stimuli to the rumen wall mechano-receptors suppressing initiation of rumination. Ingesta volume is thought to provide the physical stimuli to the rumen wall, resulting in differences in the daily time spent ruminating. Rumination index, which reflects a relationship between the amounts consumed and rumination time, was almost the same between VFAs infused and controls. Fujihara and Nakao (1982), who reported a daily ruminating time, also obtained similar results in sheep fed on timothy hay as 565.2 min that falls within the range of 500 600 min obtained in the current study. Cyclic rate, an important index for reticulo-rumen motility is reported to be reduced by ruminal infusion of acetic acid (Gregory, 1984). However, for reasons, which are not clear, results from this study show that reticulo-rumen motility was stimulated by ruminal infusion of acetic acid.

Propionic and butyric acids did not have much effect on daily ruminating time, although with an increase of $\mathrm{N}$ intake daily time spent ruminating tended to decrease $(P>0.05)$. These results are in agreement with those reported by Pearce (1965) for cattle and sheep fed on roughage. Furthermore, Pearce (1965) also observed no effect of ruminal infusion of urea on rumination behaviour, which was similar to the results obtained in this study.

Digestibility of $\mathrm{Cfi}$ was decreased $(\mathrm{P}>0.05)$ after infusion of acetic acid regardless of the level of dietary $\mathrm{CP}$ fed. This indicated that there was a shortening of the cyclic rate and thus ruminal motility, increasing digesta passage rate and reducing retention time. There was also a reduction in rumen $\mathrm{pH}$ after infusion of acetic acid could have resulted in lowered cellulolytic bacteria activities in the rumen (Fujihara et al., 2002a).

Total VFAs were not increased after ruminal infusions of acetic, propionic and butyric acids as supply of exogenous VFAs are though to prevent ruminal production of these acids, which were relatively higher in the control sheep. Also total plasma protein did not change with infusion of VFAs as values are within normal range for sheep. The concentration of urea tended to decrease after ruminal infusion of VFAs. Generally, there is a close relationship between plasma urea and ruminal ammonia concentration, so that in sheep infused with VFAs, the relative low level of plasma urea would have been a reflection of the microbial degradation of dietary protein in the rumen.

From the above results it is clear that ruminal infusion of VFAs, had no severe effect on the eating and rumination behaviour and feed utilization in shecp. However, increasing of dietary $\mathrm{CP}$ clearly prolonged rumination appearance indicating that the lag time after eating could be a response to chemo-receptors in the rumen wall caused by chemical stimuli from changing dictary CP.

It is therefore concluded that the ruminal infusion of VFAs in the rumen, did not have any effect on eating and rumination behaviour in sheep fed on hay diet, regardless changing dietary CP level. 


\section{REFERENCES}

Baile C.A., Mayer J., 1969. Depression of feed intake of goats by metabolites injected during meal. Amer. J. Physiol. 217, 1830-1836

Bailey C.B., 1961. Saliva secretion and its relation to feeding in cattle. 3. The rate of secretion of mixed saliva in the cow during eating, with an estimate of the magnitude of the total daily secretion of the mixed saliva. Brit. J. Nutr. 15, 443-451

Balch C.C., 1950. Factors affecting the utilization of food by daily cows. 1. The rate of passage of food through the digestive tract. Brit. J. Nutr. 4, 361-388

Balch C.C., 1958. Observations on the act of eating in cattle. Brit. J. Nutr. 12, 330-345

Campling R.C., Freer M., Balch C.C., 1962. Factors affecting the voluntary intake of food by cows. III. The effect of urea on the voluntary intake of oat straw. Brit. J. Nutr. 16,115-124

Campling R.C., 1966. The intake of hay and silage by cow. J. Brit. Grassl. Soc. 21, 41-48

Dryden G. McL., Stafford K.J., Waghorn G.C., Barry T.N., 1995. Comminution of roughages by red deer (Cervus elaphus) during the prehension of feed. J. Agr. Sci. 125, 407-414

Fujihara T., 1980. The eating and rumination behaviour in sheep fed only grass diets in either the fresh or dried form. J. Agr. Sci. 95, 729-732

Fujihara T., 1982. The eating and rumination behaviour in sheep fed only forage diet in dried form. Bull. Fac. Agr. Shimane University 16, 25-29

Fujihara T., Harumoto T., Abdulrazak S.A., 2002b. The effect of ruminal infusion of acetic acid on cating and rumination behaviour in sheep fed on various hay diets. J. Anim. Feed Sci. 11, 69-78

Fujihara T., Maeda S., Harumoto T,, 1990a. The effect of ruminal infusion of VFAs on the eating and rumination behaviour in sheep fed only hay. Proceedings of $5^{\text {th }}$ AAAP Animal Science Congress, Vol. 3 p. 87 Taipei (Taiwan)

Fujihara T., Nakao T., 1982. Eating and rumination behaviour in sheep given silage made from the fibrous residue of broad bean (Vicia faba L.). J. Agr. Sci. 97, 237-240

Fujihara T., Nakao T., 1984. The effect of casein supplement on the eating and rumination behaviour in sheep receiving a hay diet. Jpn. J. Zootech. Sci. 55, 199-203

Fujihara T., Nakao T., 1990a. The eating and rumination behaviour in sheep fed the silages made from the fibrous residues of broad bean (Vicia faba L.) and lucerne (Medicago sativa L.) with timothy (Phleum pratense L.) hay. Jpn. J. Zootech. Sci. 61, 666-669

Fujihara T., Nakao T., 1990b. The eating and rumination behaviour in sheep fed the diet of silage made from fibrous residue left after the extraction of Ladino clover (Trifolium repense $L$. var. giganteum) leaf protein with timothy (Phleum pratense L.) hay. Jpn. J. Zootech. Sci. 61, 757-761

Fujihara T., Nakao T., Harumoto T., 1990b. The effect of a gradual increase or decrease of daily hay intake on eating and rumination behaviour in sheep. Asian-Austr. J. Anim. Sci. 3, 187-193

Fujihara T., Sakaguchi M., Abdulrazak S.A., 2002a. The cffect of ruminal infusion of acetic and propionic acids on eating and rumination behaviour in sheep fed a low quality hay. J. Anim. Feed Sci. 11, 79-90

Fujihara T., Sumida M., Harumoto T., 1989. The effect of water consumption on eating and rumination behaviour of sheep fed only fresh or dried forage. Jpn. J. Zootech. Sci. 60, 387-395

Gordon J.G., 1958. The relationship between fineness of grinding of food and rumination. J. Agr. Sci. $51.78-80$

Gordon J.G., 1965. The relationship between rumination and the amount of roughage eaten by sheep. J. Agr. Sci. 64, 15 I-155

Gregory P.C., 1984. Inhibition of forestomach motility by short-chain volatile fatty acids in sheep. Can. J. Anim. Sci. 64, Suppl., 11-12 
Mawuenyegah P.O., Shem M.N., Warly L., Fujihara T., 1997. Effect of supplementary feeding with protein and energy on digestion and rumination behaviour of sheep consuming straw diets. J. Agr.

Sci, $129,479-484$

Pearce C.R., 1965. Rumination in sheep. IV. The investigation of some possible control mechanism. Aust. J. Agr. Res. 16, 837-853

Welch J.G., Smith A.M., 1969. Influence of forage quality on rumination time in sheep. J. Anim. Sci. $28,813-818$

Weston R.H., 1996. Some aspects of constraint to forage consumption by ruminants. Aust. J. Agr. Res. 47, 175-197

\section{STRESZCZENIE}

Wplyw infuzji kwasów octowego, propionowego i maslowego do żwacza na pobieranie paszy i przeżuwanie oraz wykorzystanie paszy przez owce żywione paszą objętościową z dodatkiem mocznika

Przeprowadzono dwa doświadczenia, w których owce żywiono sianem przy ciąłej infuzji do żwacza kwasu octowego, propionowego i masłowego, w ilości odpowiadającej 300,300 i $150 \mathrm{kcal} /$ dzień, odpowiednio. W doświadczeniu I owce otrzymywały tylko siano z tymotki, w Il siano z tymotki zawierające 6,6 i $9,1 \%$ białka ogólnego (b.og.) w s.m. lub siano z życicy wielokwiatowej o 7,3\% b. og. w s.m., bądź siano z tymotki z dodatkiem mocznika (15,5\% b. og. w s.m.). Doświadczenie przeprowadzono na 4 owcach w układzie przemiennym.

Czas pobierania paszy w ciągu dnia był dhuższy przy infuzji kwasów octowego i propionowego niż u zwierząt kontrolnych; podawanic kwasu masłowego nie powodowało zmian (doświadczenie I). Infuzja kwasu propionowego i zmiany w zawartości białka $w$ dawce spowodowały przedlużenie czasu pobierania paszy w porównanits $z$ dawką kontrolną; infuzja kwasu octowego nie powodowała takich zmian (doświadczenie II). Stwierdzono tendencję skrócenia czasu wystappienia przeżuwania po infuzji kwasu octowego i propionowego w porównaniu z kontrolą. Przy infuzji kwasu octowego otrzymano odwrotne wyniki (doświadczenie l). Wraz ze wzrostem zawartości białka ogólnego w dawce dluższy był czas pojawienia sị przeżuwania, czego nie powodowała infuzja kwasów (doświadczenie II). Stwierdzono tendencję do wydłużania się czasu przeżuwania w ciągu dnia po infuzji kwasu maslowego, a skrócenia - po infuzji kwasu octowego (doświadczenie I). Cykliczność przeżuwania miała tendencję do wydłużania po infuzji kwasu octowego w porównaniu z kontrolą; nie stwierdzono takiej tendencji po infuzji kwasu propionowego i masłowego (doświadczenie I). Cykliczność przéżuwania po infuzji kwasu octowego była mujejsza, niezależnie od poziomu białka w dawce, niż w grupie kontrolnej. Wplyw infuzji kwasu propionowego na cykliczność przeżuwania nie był wyraźny u owiec otrzymujących dawki o różnej zawartości białka ogólncgo (doświadczenic II). Cykliczność przeżuwania zmniejszała się wyrá́nie wraz ze zmniejszającą się zawartością biatka w dawkach, niezależnie od infuzji kwasów.

Otrzymane wyniki pozwalają na stwierdzenie, że infuzja LKT do żwacza ma mały wpływ na zachowanie się przy pobieraniu paszy i przeżuwanie oraz wykorzystanie paszy przez owce, oraz że raczej clemiczne niż fizyczne stymulatory, takie jak zwiększenic zawartości azotu w żwaczu, mogą wplywać na chemoreceptory ścian żwacza. 